\title{
Bolivia's
}

\section{commodity price shock}

\section{Gabriel Loza T.}

Central Bank of Bolivia

Gloza@mail.bcb.gov.bo
The adverse shock affecting commodity prices has received

little attention, at least by comparison with the recent financial crisis. The latest fall in international prices shows that, contrary to what is claimed in the empirical literature, most of these prices tend to move in unison during periods of expansion and contraction in the economic cycle. Constant shocks help account for the variability of Bolivian export prices, and the inclusion of a new sector, soya, in the export portfolio has not reduced overall risk. The conclusion is that Bolivia's policy of diversifying commodity exports has not had the effect of reducing risk, evening out cycles, reducing price volatility or increasing real export revenue. It is suggested that manufacturing exports be developed to make the country less vulnerable to shocks. 
I

\section{Introduction}

The recent international crisis and international financial shocks have focused debate on capital flows, the great volatility of these, and the contagion effect. The sharp fall in international commodity prices has not received as much attention, however. Indeed, the commodity price shock, with all the harm it has entailed for developing economies that depend on commodity exports, was one of the severest and most virulent shocks in many years, yet it appears to have gone unnoticed.

Because Bolivia is not an active participant in the international bond and share market -i.e., direct portfolio investment is not high and short-term capital mobility is low ${ }^{1}$-and because it is heavily dependent on commodity exports, international commodity price shocks need to be analysed with great care. There has been such a shock in recent years, and this has resulted in great instability and lower export revenues and real incomes in Bolivia. It has to be asked whether the price falls seen are temporary reverses that will tend to correct themselves or can be coped with by using export revenue stabilization measures, or whether, conversely, they are persistent and structural in nature, and require further-reaching measures.

Despite the shift in its economic policy since August 1985, Bolivia has not been able to increase manufacturing exports as a proportion of total exports. It has succeeded in diversifying its commodity exports, however, unlike 57 developing countries in Africa and Latin America that rely on three commodities for over $50 \%$ of their exports. According to portfolio theory, this situation should mean lower risk as long as the prices of the commodities in the export basket do not behave in the same way, i.e., as long as there are negative covariances. In the recent crisis, the prices of most of the commodities in the Bolivian export basket fell.

This paper is part of a wider study being conducted by the author at the Central Bank of Bolivia. The opinions expressed herein are not necessarily those of the Bank. The author is grateful to Boris Zambrano for drafting the econometric part of the paper under the supervision of Oscar Lora, and to Raúl Mendoza, Oscar Lora and Boris Gamarra for their comments and suggestions.

${ }^{1}$ The economy has become more internationalized in recent years with the appearance of foreign banks in the country's financial system.
Because prices moved in the same direction, portfolio risk increased.

Situations like those described have major policy implications, since if risk is rising rather than falling, if periods of declining prices coincide and shocks are persistent, it would be wrong to rely solely on an implicit policy of commodity export diversification. Rather, structural measures would be needed to raise the share of manufacturing exports.

The recent literature on commodity price fluctuations is small compared to the literature on financial crises. There is Dehn's study (2000a) of the effects of commodity price uncertainty and shocks on growth, and the work of Cashin and Patillo (2000) on terms of trade shocks in Africa. Cashin, Liang and McDermott (1999) have analysed the persistence of commodity price shocks, and Cashin, McDermott and Scott (1999b) have examined the myth of comovement in these prices. The main reference work, however, is still Reinhart and Wickham's study (1994) on the persistence or otherwise of commodity price shocks.

Against this background, the main goal of this paper is to ascertain whether the diversification of commodity exports during the crisis years of 1998 and 1999 acted as a kind of countercyclical policy that offset the negative effects of large falls in international prices, or whether, conversely, it neither lowered the portfolio risk of the export basket nor reduced the country's external vulnerability.

The specific objective is to analyse the behaviour of Bolivia's export commodity prices during the recent crisis, in order to ascertain in broad terms whether shocks are persistent or transitory, whether there are comovements in cyclical price behaviour, how volatile prices are and what degree of risk attaches to the export commodity basket.

The period of analysis, based on monthly series, runs from January 1992 to September 2000. Information on the commodity basket in this period has been produced by the Central Bank of Bolivia using December 1996 as the baseline. This provides a reference framework for analysing the external price shock in 1998 and 1999.

To this end, section II of this article reviews the theoretical and empirical literature on commodity price 
behaviour, laying stress on Prebisch's theory (1962, originally published in Spanish in 1949) of commodity price volatility and long-term deterioration in the terms of trade. Section III then analyses the trend and composition of Bolivian exports in the 1990s, the commodity price indices that are available and the behaviour of the terms of trade. Sections IV and V set out the empirical evidence for determining whether external shocks are persistent or temporary, how volatile commodity prices are, and what level of portfolio risk attaches to the export commodities basket. Section VI, lastly, sets forth some conclusions and offers some policy recommendations concerning the need to develop manufacturing exports.

\section{II}

\section{Commodity prices: some theoretical and}

\section{empirical considerations}

The subject of declining commodity prices was introduced into the economic literature by the theories of Prebisch (1962, originally published in Spanish in 1949) and Singer (1950), who stated that, in the long term, there was a permanent tendency for the terms of trade to decline, as commodity prices rose by less than those of manufactures (ECLAC, 1969).

There were originally two versions of the theory. According to Bielschowsky (1998), the first, expounded in the so-called "Latin American manifesto" (Prebisch, 1962, originally published in Spanish in 1949), stated that in the down phase of the cycle, unions in the industrialized countries managed to prevent the prices of industrial goods from falling, thereby more than offsetting the gains accruing to the periphery from cyclical upturns in commodity prices. The second version, expounded by Prebisch (1952) and subsequently developed by Lewis (1960), alluded to an excess of agricultural labour in the periphery that could not be transferred to the developed countries, and that therefore depressed the prices of that sector's output. Ultimately, as Ros (1998) shows, both versions centre on the relative rigidity of labour markets in developed and developing countries.

A third, more elegant version, based on Singer (1950), focused on differences in the price elasticity of demand and income elasticity for commodities, which were less than one. The expanded version given in ECLAC (1969), however, suggests that if prices strictly reflected the cost reductions yielded by technical progress, industrial prices would fall by more than commodity prices, because productivity rises by more in industry than in primary activities. Since technical progress is distributed unevenly among countries, the periphery tends to transfer some of the benefits of its technical progress to the central countries, while the latter retain the benefits of theirs.

Pure international trade theory saw deteriorating terms of trade as an esoteric technical problem, while in the political sphere it was a very emotionally charged issue. Besides the long-term decline of commodity prices, there was the subject of export price instability, although Krueger (1984) maintains that strictly these are two separate issues. The empirical literature downgraded the proposition to the level of a hypothesis, ${ }^{2}$ considering that the evidence was not conclusive. The empirical basis taken by Prebisch covered the period from 1870 to 1930 and used British export prices as a proxy for manufactured goods prices and British import prices as a proxy for commodity prices. In a 1980 study, Spraos concluded that there probably was a long-term decline in the period looked at by Prebisch, but that it was very questionable whether the same had occurred since the post-war period. Even Michaely stated in 1982 that poor countries' export prices rose more quickly in the $1952-1973$ period than those of rich countries.

Sprout (1992) notes that efforts to prove the theory have produced discouragingly inconsistent results and concludes, using a quantitative criterion, that a third of the most important studies bear out Prebisch's hypothesis while a quarter refute it.

The subject of price instability has also been seen as quite contradictory and inconclusive, and the view

\footnotetext{
${ }^{2}$ Concerning this point and the references to Spraos and Michaely further on in the paragraph, see Borensztein, Khan and others (1994).
} 
taken has been that even in the short term this instability has been exaggerated (Krueger, 1984, p. 595).

The policies recommended by IMF for coping with balance-of-payments disequilibria caused by declining export revenues basically come down to two: compensatory emergency financing, established in 1964, and price stabilization funds for specific products. These measures were based on the assumption that imbalances were temporary.

In the mid-1990s, stress was again placed on the persistence of commodity price shocks by the empirical work of Reinhart and Wickham (1994), who found the following patterns for the period 1957-1993 by breaking down time series between long-term and cyclical tendencies:

- The weakness of real commodity prices is longterm and persistent, and is not due to temporary deviations from the trend.

- The relative importance of permanent price shocks varies depending on the product group taken, being lowest for metals and highest for beverages (coffee, tea).

- The characteristics of the cycle vary by product, being less persistent for metals and more persistent for beverages.

- Average prices are strikingly low and a steady increase is seen in the variance of commodity prices. The coefficient of variation rises sharply and prices become more volatile around the mean.

The recommendations of the study cited emphasized the need to adopt structural policies like export diversification, given that price weakness was long-term. Because prices were so volatile, however, they also considered it advisable to use coverage strategies and stabilization funds.

Only in the late 1990s, however, did the empirical literature show a renewed interest in commodities. Cashin, Liang and McDermott (1999) relied on estimation of the unbiased median, which is better than the unit root test for determining the persistence of commodity price shocks, and used monthly information on 60 commodities for the period 1957-1998. Their study found that, for most commodities, price shocks were typically long-lasting and that their persistence was quite variable. It also found differences among groups of products, persistence being greater for metals than for woods. Consequently, it concluded that it was wrong to see commodity price shocks as a temporary phenomenon: when they are persistent, an adverse shock is likely to depress prices for a long time. It follows from this that measures such as compensatory financing and stabilization funds are probably not effective and that consumption smoothing is unsustainable.

In their analysis of the duration and scale of commodity price cycles, based on monthly series for 36 products, Cashin, McDermott and Scott (1999a) find the following for 1957-1999:

- Price cycles are asymmetrical, with the down stage lasting at least a year longer than the up stage.

- Prices fall by more in the down phase of the cycle than they rise in the recovery phase, while they move faster in the up stage than in the down stage.

- There is little evidence that the price cycle takes a consistent form.

- There is no relationship of dependence between the duration of the down phase and the duration of the up phase. If large adverse price movements continue for a long time, this does not make it more likely that the down phase will end with the beginning of the recovery phase.

A recent study by Cashin, McDermott and Scott (1999b), using monthly information for the period 1957-1999, finds empirical evidence that commodity prices do not move in unison, except where the products are directly related (in the same sector or branch). Defining comovement as concordance, i.e., the proportion of time spent by the prices of two commodities in the same upward or downward phase, it does not find any evidence that these prices move together, except for gold and petroleum. The policy conclusions that can be drawn are important, since if commodity prices moved together, risk could only be reduced by diversifying into manufactured exports, for which the country concerned might have no comparative advantages. Conversely, if there are no comovements then commodity exports themselves can be diversified.

After many years, the subject of terms of trade shocks has been reinvigorated. Cashin and Patillo (2000) note that this is one of the most important relative prices and that economists are ignorant of many of its empirical properties. In their study of 42 countries in sub-Saharan Africa in the period 1990-1996, they find that in half of them shocks are short-lived, lasting less than four years, whereas in a third shocks are permanent. Discussing the policy implications, they say that if shocks are short-lived then there is scope for smoothing the path of national consumption by 
modifying patterns of national saving and international financing. But if shocks are long-lasting, countercyclical policies will be of little help in establishing a new equilibrium.

The effects of shocks on economic growth has been dealt with in Dehn (2000b); dependence on commodity exports means that adverse shocks have not just an ex post effect but also an ex ante one of uncertainty, a combination which reduces growth prospects. Positive shocks, by contrast, are rapidly diluted and do not have any major long-term effects.
To sum up, the recent empirical and theoretical literature has not attached the same importance to commodity price shocks as to financial crises. Empirical evidence has now been found to show that these shocks are persistent and that the downward phase of price movements lasts longer than the upward phase. In other words, certain facts seem to bear out the idea that there is a long-term trend towards lower prices. There is also empirical evidence, however, which goes against the perception that commodity prices move together, and this seems to rule out price falls across the board.

\section{III}

\section{The trend and composition of}

\section{Bolivian exports}

This part of the paper will briefly analyse the trend and composition of Bolivian exports, and will present the price index for the country's commodity export basket and the monthly terms of trade index for commodities against manufactures.

Over a longer period, the latter index shows that the terms of trade for the Bolivian economy have been deteriorating steadily and persistently since 1980 . Prices fell twice in the 1980s, first in 1981 and 1982, when they dropped by $8.3 \%$ and $11.2 \%$, respectively, and then between 1985 and 1987, when they declined by about $12 \%$ a year. In both cases, lower prices for minerals, particularly tin, were the main cause. Subsequently, in the 1990s, there were two major terms of trade shocks. The first one lasted four years, beginning in 1992 when the terms of trade fell by $16 \%$, partly because of lower gas prices following changes to the contract under which gas was exported to Argentina. The second one, which was briefer, occurred in 1998, and was associated with the Asian crisis and the international financial crisis. This time the decline was $5 \%$.

The terms of trade (figure 1) have fluctuated, with long periods of decline and very few years of recovery between 1980 and 2000 .

\section{Bolivian exports in the 1990s}

Between 1990 and 1999, Bolivia's nominal export revenues averaged US\$ 1,018.7 million dollars a year ( $15 \%$ of GDP). These revenues were quite volatile, with

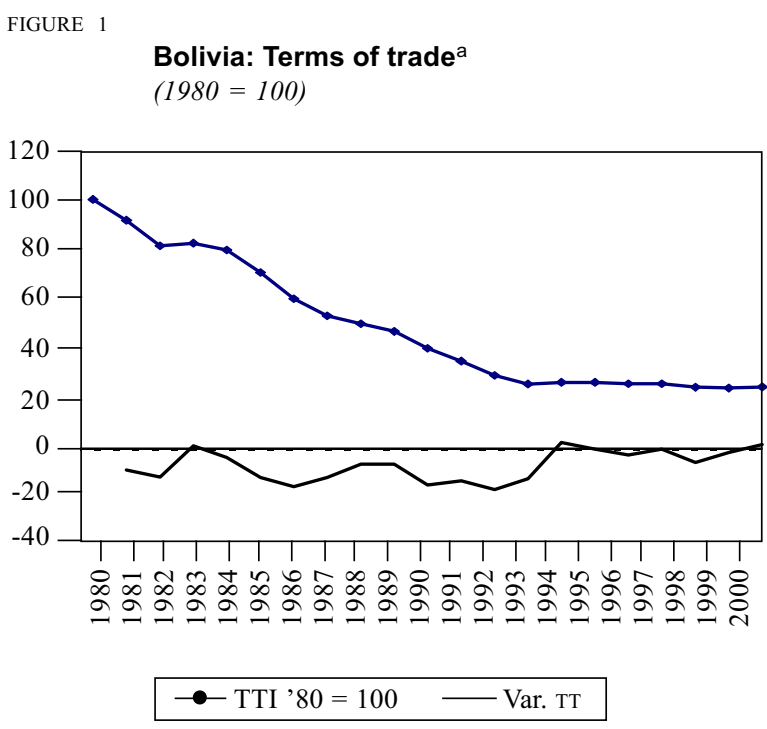

Source: Prepared by the author on the basis of data from the National Institute of Statistics (INE).

a тTI: terms of trade index. Var. тт: percentage variation in тті.

a standard deviation of US\$ 176.8 million, equivalent to $17 \%$ of the average.

The nominal value of exports grew by $1.1 \%$ a year over the decade, a very low rate when compared, for instance, with the figures for the whole world (5.5\%), South America (4.9\%) and Chile (7.2\%). In real terms, exports fell by $5.7 \%$ over 10 years, with two periods of decline: between 1990 and 1992, when they fell by $27 \%$ 
owing to a drop in gas exports to Argentina, and in 1998 and 1999, when the international crisis resulted in a cumulative fall of $16 \%$. In the $1990 \mathrm{~s}$, then, the Bolivian economy experienced two external shocks resulting in large falls in real export revenue (table 1).

The poor performance of Bolivian exports contrasts with the dynamism of world trade. Whereas Bolivian exports increased by just $10 \%$ in nominal terms over 10 years, world exports increased by $60 \%$.

The composition of Bolivian exports in the 1990s continued to be dominated by commodities, although their share of the export total fell slightly from $86.6 \%$ in 1990 to $84 \%$ in 1999 . The share of manufactured exports, meanwhile, increased by less than one percentage point in 10 years, from $13.2 \%$ to $14 \%$.

Structurally, Bolivian exports are highly asymmetrical compared to world exports. According to WTO (2000), manufactures make up over three quarters of world exports, but less than a sixth of Bolivian exports. This share is lower than that of the African countries (30\%), and far below the Latin American average $(60 \%)$. Consequently, the slow increase in Bolivian exports is basically due to the sluggish growth of its commodity exports. Manufacturing exports rose by more than $3.5 \%$ a year over the decade, but are only a small part of the total.

The various primary exports behaved very differently over the decade. Bolivia's agricultural exports grew by $10.3 \%$ a year, which is well above the world average of $3.1 \%$, while hydrocarbon exports fell by $11 \%$ a year owing, as already mentioned, to the ending of the contract to export gas to Argentina. The country's mining exports were stagnant over 10 years, while exports of this type grew by $1.5 \%$ a year worldwide.

This lack of export dynamism was due to falling unit export prices, since while the value index rose by $10 \%$, the volume index rose by $57 \%$, implying a contraction of $30 \%$ in the export unit value index. This drop was greater than the decline in world unit prices for mining (22\%) and agriculture ( $8 \%$ ), and greater too than the fall in the commodity price index (13\%). Part of the explanation lies in the drastic two-thirds reduction in the gas price set in the contract with Argentina, which took place between the first quarter of 1991 and the second quarter of 1992.

Not only did Bolivian export prices decline, but unit import prices rose by $17.1 \%$, resulting in a sharp deterioration $(40 \%)$ in the terms of trade. Excluding the initial effect of the fall in the gas price in the early 1990 s, the deterioration was $22 \%$. The effect of the
TABLE 1

Bolivian export values, nominal and real terms ${ }^{a}$

(Millions of dollars)

\begin{tabular}{lrcr}
\hline Year & $\begin{array}{c}\text { Nominal } \\
\text { value }\end{array}$ & $\begin{array}{c}\text { Import price } \\
\text { index }\end{array}$ & $\begin{array}{r}\text { Real } \\
\text { value }\end{array}$ \\
\hline 1990 & 937.5 & 100.0 & 937.5 \\
1991 & 873.8 & 105.5 & 828.2 \\
1992 & 742.1 & 108.5 & 684.0 \\
1993 & 786.7 & 110.7 & 710.7 \\
1994 & $1,091.0$ & 114.1 & 956.2 \\
1995 & $1,139.1$ & 118.2 & 963.7 \\
1996 & $1,216.2$ & 121.1 & $1,004.3$ \\
1997 & $1,255.6$ & 120.0 & $1,046.3$ \\
1998 & $1,110.1$ & 118.4 & 937.6 \\
1999 & $1,034.8$ & 117.1 & 883.7 \\
GGR & 1.1 & 1.8 & -0.7 \\
\% var. 99/90 & 10.4 & 17.1 & -5.7 \\
Mean & $1,018.7$ & 113.4 & 895.2 \\
SD & 176.8 & 7.0 & 120.2 \\
CV & 0.17 & 0.06 & 0.13 \\
\hline
\end{tabular}

Source: Prepared by the author on the basis of data from the National Institute of Statistics (INE).

a GGR: geometric growth rate. SD: standard deviation. $\mathrm{CV}$ : coefficient of variation.

terms of trade on export revenue, as estimated by INE, was such that if export prices had behaved in the same way as import prices in 1999, the country would have had US\$ 597 million more revenue. The deterioration of the terms of trade means that Bolivia is transferring part of its domestic production effort abroad and losing revenue in real terms. What happened in the country in the 1990s is an empirical demonstration of this.

In summary, the poor performance of Bolivian exports stands in contrast to the dynamism of world exports, most of which are manufactures, owing to the country's dependence on commodities whose prices experienced two severe external shocks in the 1990s, with adverse effects for real export revenues.

\section{The price index for the Bolivian export commodity basket}

The structure of Bolivian exports is heavily skewed towards commodities, which account for $84 \%$ of the total. A wide range of commodities is involved, and exports are not dominated by just a handful of products as is usually the case in developing countries. They are drawn from different sectors of the economy, having ceased to depend on any particular one.

The Central Bank of Bolivia uses several indices to measure prices and price variations for commodities 
in the export basket. The basket consists of 13 commodities, or 11 if hydrocarbons are excluded (table 2).

This basket has the following characteristics:

- For each product on which daily information is available, the price is multiplied by its weighting in the basket as determined by its share of export value in 1996. The Laspeyres index is therefore used, i.e.:

$$
\mathrm{LPI}=\frac{\Sigma \mathrm{Pn} \mathrm{Qo}}{\Sigma \mathrm{Po} \mathrm{Qo}}
$$

- Commodities accounted for $80.5 \%$ of the value exported in 1996 , falling to $68.8 \%$ if hydrocarbons are excluded. The index is calculated with and without fuels (IMF also does this) to separate out the effects of large oil price swings.

- The information is available in real time through the Reuters service, except in the case of woods, for which the information source is the ViceMinistry of Exports, and of natural gas, information on which is provided by Yacimientos Petrolíferos Fiscales Bolivianos (YPFB), which releases price information a month in arrears.

- The baseline is the December 1996 price. This is consistent with the base year for calculating the effective real exchange rate.

The 13 products in the basket were grouped into three sectors so that sectoral behaviour could be differentiated: the mining sector, which includes four products; the agricultural sector, which includes seven products; and the hydrocarbons sector, which covers gas and petroleum. Since gas and petroleum do not behave alike, however, because of the gas export contract with Argentina, they are considered separately for practical reasons. In the case of agricultural products, a subgroup, the soya complex,
TABLE 2

Bolivia: Export commodity basket, 1996

(Percentage share of total exports)

\begin{tabular}{llr}
\hline Commodity & Pricing & 1996 \\
\hline Zinc & CUS/FLB & 13.5 \\
Gold & US/FTO & 10.5 \\
Tin & US/FL & 7.5 \\
Silver & US/FTO & 5.6 \\
Soya beans & US/MT & 5.3 \\
Soya meal & US/MT & 9.0 \\
Soya oil & US/MT & 3.6 \\
Woods & US/MT & 6.9 \\
Cotton & US/MT & 2.9 \\
Coffee & UUS/LB & 1.4 \\
Sugar & US/MT & 2.6 \\
Gas & US/TCF & 8.3 \\
Petroleum & US/BARREL & 3.4 \\
& & \\
Total commodities & & 80.5 \\
Ex-fuel total & & 68.8 \\
Total exported & & 100.0 \\
\hline
\end{tabular}

Source: Prepared by the author on the basis of data from the Central Bank of Bolivia.

a US: dollars. CUS: cents. LB: pound. FLB: fine pound. MT: metric tons. TCF: thousands of cubic feet. FTO: fine troy ounce.

was created. This includes soya beans, soya meal and soya oil. Each product kept its weighting, so the weighting of the sector in the total is the sum of each of its products.

In summary, the following indicators are available:

- Price indices for each product: 13 in all.

- Overall price index (OPI).

- Overall price index without fuel (OPI w/f).

- Mining price index (MPI).

- Agricultural price index (API).

- Price index for the soya complex.

\section{IV}

\section{The commodity price trend, shocks and comovements}

This part of the paper will use empirical indicators to analyse the trend of commodity prices, short-term shocks that have affected them and their recent decline, to determine whether their behaviour is temporary and the shock will tend to subside, or whether there is a permanent or structural component. It will also try to judge whether the prices of commodities in the export basket are moving in unison, i.e., whether their rising 
FIGURE 2
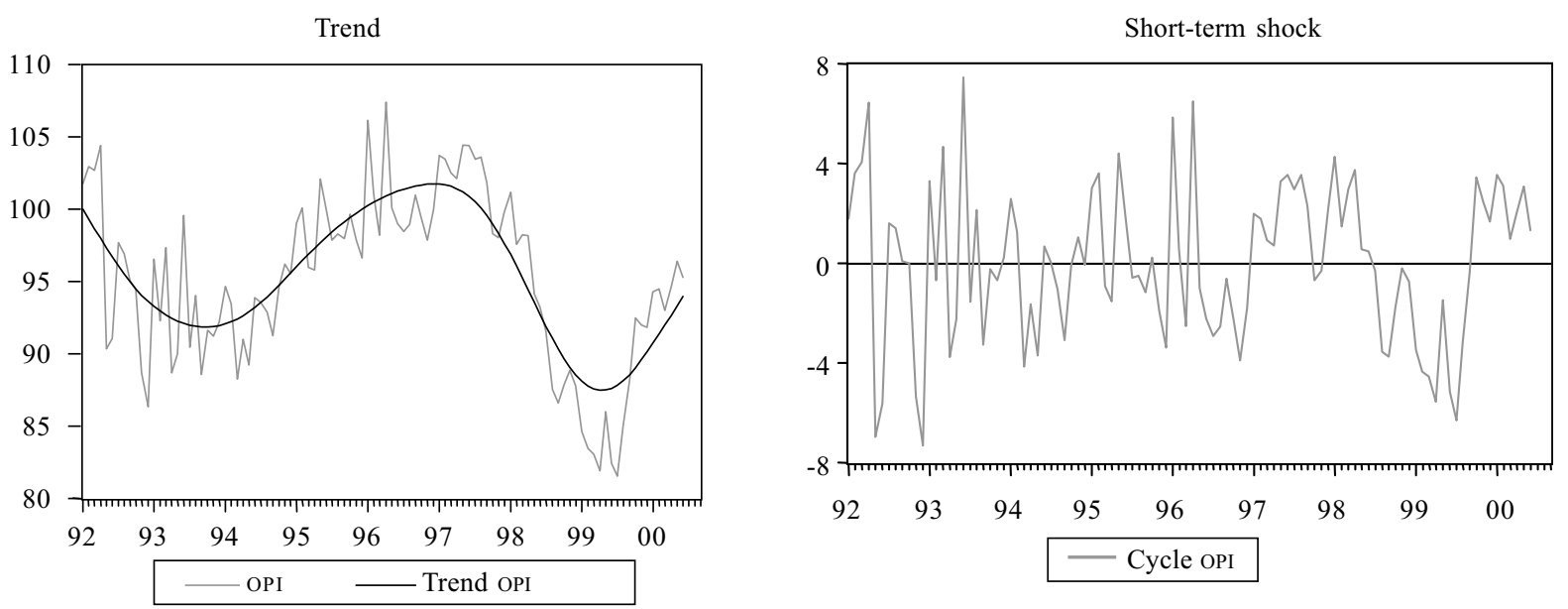

Source: Prepared by the author on the basis of data from the Central Bank of Bolivia.

and falling periods coincide, or whether they behave countercyclically so that an upward movement in one commodity is offset by a downward movement in another.

\section{The trend of commodity prices}

To analyse the behaviour of commodity prices in the 1990 s, using the overall and ex-fuel indices, price time series were broken down into two components: longterm trend and short-term shock.

From January 1992 onward, commodity prices moved in short bursts (lasting about eight months) of contraction and recovery, but in April 1994 the index began a 25 -month period of increase, the longest in the decade, peaking in April 1996 at 107.4 (figure 2). Then the short cycle (six months) of contraction and recovery returned, until in June 1997, with the Asian crisis, the longest downward cycle of the 1990s began ( 25 months). This ended in July 1999 when the price index bottomed out at 81.5. Only in August 1999 did prices begin to recover steadily, and this lasted until May 2000, after which they climbed more erratically until September the same year. For petroleum the recovery phase began earlier, in March 1999, when the Organization of the Petroleum Exporting Countries (OPEC) decided to cut output.

The longest period of rising prices (25 months) had the same duration as the longest period of falling prices. The drop in prices during the downward phase
(13.8\% in the overall index and $15.2 \%$ in the ex-fuel index) was larger than the increase during the upward phase $(10.8 \%$ in the overall index and $11.7 \%$ in the exfuel index). The overall index stood at 81.6 at the beginning of the recovery phase in 1999 , which is below the 88.6 value at which recovery began in 1993 .

The long-term trend, obtained using the HodrickPrescott filter smoothing method (Hodrick and Prescott, 1997), has the wave pattern which is a key characteristic of commodity prices ${ }^{3}$ (figure 2 ).

The Hodrick-Prescott filter is a two-sided linear filter that computes a smoothed series $s$ of $y$, minimizing the variance of $y$ around $s$, while subjecting it to a penalty that constrains the second difference of $s$. This means that the Hodrick-Prescott filter chooses $s_{t}$ to minimize the following objective function:

$$
\sum_{t=1}^{T}\left(y_{t}-S_{t}\right)^{2}+\lambda \sum_{t=2}^{T-1}\left\{\left(s_{t+1}-S_{t}\right)-\left(s_{t}-S_{t-1}\right)\right\}^{2}
$$

The penalty parameter $\lambda$ controls the smoothness of the $s_{t}$ series. The larger $\lambda$ is, the smoother the series. If $\lambda \rightarrow \propto, s_{t}$ approximates to a linear trend. In this paper, $\lambda=14,400$, following Hodrick and Prescott's suggestion for monthly series.

Smoothing the trend in the 1990s, we end up with a wave pattern that begins with an 18-month-long contractionary phase, lasting until August 1993. This is followed by a long recovery phase, lasting 36 months,

\footnotetext{
${ }^{3}$ See Cashin, McDermott and Scott (1999a).
} 
that ends in August 1996, then by a 49 month contractionary phase and the onset of a recovery phase in mid-1999 and the first three quarters of 2000.

The series showing the short-term price shocks is obtained residually as the difference between the longterm trend series and the original series. It shows that prices are below trend in a falling market and above trend in a rising market. Between 1992 and 1996 they fluctuate greatly, but from December 1996 until April 1998 there is a sustained, 17-month recovery during which prices are above trend. Between May 1998 and September 1999, however, prices are well below trend, suggesting that the adverse effect of the price shock was felt most in this period, although the decline had begun earlier, in June 1997. Prices thus fell to a level nine points below the index trend value, as happened in April and July 1999.

\section{Persistent or temporary shock?}

To determine how important a role is played by persistent shocks, a two-stage procedure was followed. Firstly, the properties of the time series were established using the Dickey-Fuller and augmented Dickey-Fuller tests for unit roots. Table 3 gives the critical values for the level and first-difference tests. If $y$ is stationary, the shocks are transitory; if $y$ is an order one integrated process, on the other hand, then there is a permanent component.

In the second stage, the size of the permanent component was determined using Cochrane's methodology, which measures the persistence of shocks by examining the variance of their differences. This has the following form:

$$
\mathrm{PS}=\left(\frac{1}{k}\right) * \frac{\operatorname{var}\left(y_{t}-y_{t-k}\right)}{\operatorname{var}\left(y_{t}-y_{t-1}\right)}
$$

On the basis of the persistence statistic (PS), if the ratio equals 1 , the variable $y$ follows a random walk and all the shocks are permanent. If $y$ is stationary, all the shocks subside so that the ratio tends to zero, indicating that the shocks will be temporary. If $y$ is an integrated order one process, it has transitory and permanent components, so that the ratio will converge on the ratio between the variance of the permanent shock and the total variance of variable $y$. Thus, the closer the ratio is to one, the larger the permanent component and the less the relative importance of temporary shocks. This measurement was applied for $\mathrm{k}=1,12$ and 24 lags as the data are monthly (table 4).

In the case of Bolivia, the price series with and without fuels and by sector (metals, agriculture, soya complex and fuels) are integrated and follow an order one process. It was found that in each price series (overall and sectoral), permanent shocks played a role in explaining the variance of monthly prices.

The effect of the permanent component of shocks is greater for metal prices (accounting for 69\% of

TABLE 4

Bolivia: Persistence of shocks in
export price indices

(Variance ratios)

\begin{tabular}{lccc}
\hline & \multicolumn{3}{c}{ Lags $(\mathrm{t})$} \\
\cline { 2 - 4 } & 1 & 12 & 24 \\
\hline Commodities & 1 & 0.34 & 0.26 \\
Ex-fuel commodities & 1 & 0.38 & 0.38 \\
Agricultural & 1 & 0.28 & 0.24 \\
Metals & 1 & 0.69 & 0.35 \\
Soya complex & 1 & 0.41 & 0.40 \\
Fuels & 1 & 0.26 & 0.21 \\
\hline
\end{tabular}

Source: Prepared by the author on the basis of data from the Central Bank of Bolivia.

TABLE 3

Unit root analysis: ${ }^{a}$ Dickey-Fuller test and augmented Dickey-Fuller test

\begin{tabular}{|c|c|c|c|c|c|c|c|c|c|c|c|}
\hline \multirow[t]{2}{*}{ Series } & \multicolumn{3}{|c|}{ Levels } & \multicolumn{2}{|c|}{ Critical values } & \multicolumn{3}{|c|}{ First differences } & \multirow{2}{*}{$\begin{array}{c}\text { Order of } \\
\text { integration }^{\mathrm{b}}\end{array}$} & \multicolumn{2}{|c|}{ Critical values } \\
\hline & No. lags & Model & t-Statistic & $1 \%$ & $5 \%$ & No. lags & Model & t-Statistic & & $1 \%$ & $5 \%$ \\
\hline OPI & 4 & $\mathrm{C}$ & -1.416578 & -4.055 & -3.4561 & 4 & B & -5.217714 & $1(1)$ & -3.4993 & -2.8915 \\
\hline OPIWF & 4 & $\mathrm{C}$ & -1.343285 & -4.0521 & -3.4548 & 4 & $\mathrm{~A}$ & -4.471892 & $1(1)$ & -2.5866 & -1.9433 \\
\hline Agriculture & 4 & $\mathrm{C}$ & -1.511792 & -4.0521 & -3.4548 & 5 & $\mathrm{~A}$ & -4.587867 & $1(1)$ & -2.5868 & -1.9434 \\
\hline Soya complex & 4 & $\mathrm{C}$ & -1.5352 & -4.0521 & -3.4548 & 0 & A & -13.7045 & $1(1)$ & -2.5858 & -1.9432 \\
\hline Metals & 2 & $\mathrm{C}$ & -3.0101 & -4.0503 & -3.4539 & 2 & $\mathrm{C}$ & -5.35682 & $1(1)$ & -3.4972 & -2.8906 \\
\hline Fuels & 6 & $\mathrm{C}$ & -1.616115 & -4.054 & -3.4557 & 8 & A & -3.1834 & $1(1)$ & -2.5883 & -1.9436 \\
\hline
\end{tabular}

Source: Prepared by the author on the basis of data from the Central Bank of Bolivia.

a A: Does not include deterministic components. B: Includes constant but not trend. C: Includes constant and trend.

b When the first-differenced t-statistic is above the critical values, the series are integrated series of order one. 
monthly variance) than for the agricultural and fuel sectors, where the figure is $25 \%$, or the overall indices (with and without fuels), where it is about $33 \%$. In the metals price series this component displays a low level of persistence, falling from $69 \%$ to $35 \%$ at 24 months. In the other sectors and the overall index, the permanent component does not fall off in this way. Price stabilization policies, like the ones recommended by the International Monetary Fund (IMF), can be used to deal with transitory shocks.

The presence of permanent shocks, however, indicates that the commodity price weakness seen since 1997 is not just a transitory phenomenon, the effect of an abnormal cycle associated with the Asian crisis (even if the downward phase did begin with this crisis). Consequently the decline did not automatically reverse itself, nor have prices rebounded since the Asian economies recovered in 1999. Likewise, the fall in prices was not associated with cyclical fluctuations in the world economy, as it occurred when the United States economy was in the midst of a high growth period and when the world economy was also growing. Except in the case of petroleum, prices have recovered more slowly than expected, and they have yet to return to the levels seen before the upturn began.

To sum up, in Bolivia commodity price shocks have a permanent component, although it is smaller than the developing country average. ${ }^{4}$ The sector in which this component is largest is metals, although it is not very persistent there. As a result, the recent price shock has not tended to abate rapidly.

\section{Concordance or comovement in the phases of price cycles}

The cyclical behaviour of prices raises the question of whether sectoral and product price series move together in the upward and downward phases of the cycle. Concordance is a measure of comovement that can be used to compare the cyclical patterns of price series. The statistical evidence is used to establish the proportion of time for which the prices of two commodities are concurrently in the same phase of the cycle. $^{5}$

For this purpose, a dichotomous variable is specified for each original variable or price series,

\footnotetext{
${ }^{4}$ See Cashin, Liang and McDermott (1999).

${ }^{5}$ For a more detailed explanation of concordance, see Cashin, McDermott and Scott (1999b).
}

taking the value unity when the variable is in the upward phase and zero when it is in the downward phase. The degree of concordance between the cycles of two price series is then:

$$
C_{i j}=T^{-1}\left\{\sum_{t=1}^{T}\left(S_{i, t} S_{j, t}\right)+\left(1-S_{i, t}\right)\left(1-S_{j, t}\right)\right\}
$$

where $C_{i j}$ is the concordance statistic measuring the proportion of time for which two price series are in the same state, $T$ is the sample size, $S_{i, t}$ is the dichotomous variable associated with the original variable $x_{i}$ at time $t$, and $S_{j, t}$ is the dichotomous variable associated with original variable $x_{j}$ at time $t$.

When the concordance statistic takes values close to unity, the price series being compared are procyclical; when the statistic is close to zero, the price series are countercyclical, and when the concordance takes values close to 0.5 , the series are equally likely to be procyclical or countercyclical. For practical purposes, in this study an arbitrary range of $+/-0.1$ is taken ${ }^{6}$ purely to differentiate cases close to 0.5 , so that a ratio of over 0.6 would indicate that the series tended to be procyclical and one of under 0.4 that they tended to be countercyclical.

The results for the period January 1992 to September 2000 show (table 5) that the series for the ex-fuel price index displays a high degree of concordance $(0.71)$ with the fuel price series. In other words, they are procyclical variables. Consequently, being a fuel exporter does not insulate a country from the general commodity cycle. Similarly, if fuels are excluded the behaviour of other export commodities is procyclical. This can be seen most clearly at the sectoral level, agricultural commodity prices being more procyclical with fuel prices $(0.81)$ than are metal prices (0.60).

In the $1990 \mathrm{~s}$, Bolivia made progress with agricultural exports, particularly those of the soya complex. It was supposed that this diversification would reduce the country's dependence on the mining sector. But the sectoral concordance indicators make it difficult to say whether or not metal prices are procyclical in relation to the prices of agricultural commodities $(0.45)$ or the soya complex $(0.48)$, since the concordance indicators are very close to 0.5 .

The next step, however, is to carry out a productby-product analysis to identify any comovements

\footnotetext{
${ }^{6}$ More detailed analysis would be needed to demonstrate what range might be appropriate for differentiating cases close to 0.5 .
} 
Bolivia: Concordance among sectors

\begin{tabular}{|c|c|c|c|c|c|c|}
\hline & Metals & $\begin{array}{c}\text { Soya } \\
\text { complex }\end{array}$ & $\begin{array}{l}\text { Agricultural } \\
\text { sector }\end{array}$ & Fuels & $\begin{array}{l}\text { Overall price } \\
\text { index (OPI) }\end{array}$ & $\begin{array}{c}\text { Ex-fuel } \\
\text { OPI }\end{array}$ \\
\hline Metals & 1.000 & & & & & \\
\hline Soya complex & 0.476 & 1.000 & & & & \\
\hline Agricultural sector & 0.448 & 0.724 & 1.000 & & & \\
\hline Fuels & 0.600 & 0.533 & 0.810 & 1.000 & & \\
\hline OPI & 0.505 & 0.705 & 0.943 & 0.752 & 1.000 & \\
\hline Ex-fuel OPI & 0.771 & 0.381 & 0.657 & 0.714 & 0.676 & 1.000 \\
\hline
\end{tabular}

Source: Prepared by the author on the basis of data from the Central Bank of Bolivia.

between commodity prices in the mining sector and the agricultural sector (table 6). Out of 28 possible combinations between pairs of agricultural and mining products in the export basket, there seem to be nine pairs of commodities (32\%) whose price series move together in the phases of the cycle, i.e., these commodities are procyclical. The most procyclical are gold, silver, cotton and soya oil. Fewer pairs (six) are countercyclical, the clearest price relationships being between tin and soya (0.33) and silver and soya (0.22).

As regards fuels, it seems that the prices of mining commodities, except silver, and of agricultural commodities, except soya oil, are procyclical with respect to gas prices. This indicator is significant, since for the decade beginning in 2000 hopes have been centred on exports of gas, in relation to which very few products are countercyclical. As regards petroleum prices, countercyclical products seem to include mining commodities, other than silver, and agricultural commodities, other than woods and sugar.

To sum up, in Bolivia, by contrast with what Cashin, McDermott and Scott (1999b) found for developing countries generally, there is a high degree of concordance at the sectoral level, suggesting that commodity export diversification has not offset the effects of the price cycle, i.e., diversification has not been countercyclical. At the product level, however, a third of exports are found to be countercyclical. The

\begin{tabular}{|c|c|c|}
\hline & $\begin{array}{l}\text { Bolivia: Concordanc } \\
\text { commodity and met }\end{array}$ & agricultural \\
\hline Mining & Agriculture & Concordance \\
\hline \multicolumn{3}{|c|}{ Procyclical commodities } \\
\hline Gold & Soya beans & 0.62 \\
\hline Gold & Cotton & 0.73 \\
\hline Gold & Coffee & 0.61 \\
\hline Gold & Sugar & 0.68 \\
\hline Gold & Soya oil & 0.70 \\
\hline Zinc & Cotton & 0.61 \\
\hline Tin & Soya oil & 0.70 \\
\hline Silver & Soya oil & 0.73 \\
\hline Silver & Wood & 0.62 \\
\hline \multicolumn{3}{|c|}{ Countercyclical commodities } \\
\hline Zinc & Wood & 0.32 \\
\hline Gold & Wood & 0.39 \\
\hline Tin & Soya beans & 0.33 \\
\hline Tin & Soya meal & 0.37 \\
\hline Silver & Soya beans & 0.22 \\
\hline Silver & Soya meal & 0.18 \\
\hline
\end{tabular}

Source: Prepared by the author on the basis of data from the Central Bank of Bolivia.

prices of silver and tin (13.1\% of exports in 1996) seem to be countercyclical in relation to soya beans and soya meal (14.3\% of exports in 1996), and those of silver seem to be countercyclical in relation to gas $(8 \%)$. 


\section{Export price volatility and portfolio risk}

This part of the article supplements the examination of export commodity price behaviour with an analysis of price volatility using the coefficient of variation, which relates the standard deviation to the average, ${ }^{7}$ and with calculations of portfolio risk for products in the export basket.

\section{Export price volatility}

It is generally accepted that high volatility is an important characteristic of commodity price behaviour. In the case of Bolivia, both the overall price index and the ex-fuel index have a volatility of 0.06 (table 7). In the overall index volatility is lower than the 0.135 calculated by Cashin, Liang and McDermott (1999) for

${ }^{7}$ As fractions of one. The coefficient of variation is usually expressed as a percentage (Moya, 1991). a basket of 56 commodities in the period 1957-1998, while it is somewhat higher than the 0.04 calculated for the ex-fuel basket.

At the sectoral level, metal prices (0.05) are the least volatile and fuel prices $(0.22)$ are the most volatile, with agricultural commodity prices somewhere in between (0.11). To turn to specific commodities, prices for soya meal $(0.21)$ and soya oil $(0.25)$ are highly volatile, on a par with fuels, while coffee, sugar and cotton prices are among the most volatile in the Bolivian export basket.

Changes in volatility are calculated here for the period from January 1992 to September 2000, and are measured using cumulative values for annual average coefficients of variation (figure 3 ). In the case of the overall price index including fuels it is found to have remained fairly steady, with a rise in volatility since 1997, while volatility in the ex-fuel index has been

TABLE 7

Bolivia: Statistics describing commodity price indices, January 1990 to September 2000

\begin{tabular}{|c|c|c|c|c|c|}
\hline & Mean & $\begin{array}{l}\text { Standard } \\
\text { deviation }\end{array}$ & $\begin{array}{l}\text { Coefficient } \\
\text { of variation }\end{array}$ & $\begin{array}{c}\text { Coefficient } \\
\text { of asymmetry }\end{array}$ & $\begin{array}{l}\text { Coefficient } \\
\text { of kurtosis }\end{array}$ \\
\hline Zinc & 105.52 & 12.52 & 0.12 & 0.68 & 3.56 \\
\hline Gold & 88.97 & 9.61 & 0.11 & -0.22 & 1.69 \\
\hline Tin & 94.09 & 7.59 & 0.08 & -0.11 & 3.66 \\
\hline Silver & 97.72 & 14.57 & 0.15 & -0.07 & 3.18 \\
\hline Metals index & 97.33 & 5.05 & 0.05 & 0.02 & 3.02 \\
\hline Soya beans & 93.65 & 14.23 & 0.15 & 1.36 & 5.52 \\
\hline Soya meal & 83.10 & 17.27 & 0.21 & 0.66 & 2.82 \\
\hline Soya oil & 104.93 & 27.41 & 0.26 & 2.62 & 18.57 \\
\hline Soya complex & 90.73 & 14.29 & 0.16 & 0.29 & 3.06 \\
\hline Wood & 94.13 & 18.36 & 0.20 & -0.08 & 3.12 \\
\hline Cotton & 91.27 & 29.79 & 0.33 & 2.12 & 11.77 \\
\hline Coffee & 90.66 & 36.05 & 0.40 & 0.71 & 4.63 \\
\hline Sugar & 100.10 & 33.29 & 0.33 & 2.15 & 14.98 \\
\hline Agricultural index & 92.14 & 10.49 & 0.11 & 0.26 & 2.42 \\
\hline Gas & 97.10 & 25.15 & 0.26 & 2.57 & 12.25 \\
\hline Petroleum & 77.11 & 18.26 & 0.24 & 1.02 & 4.92 \\
\hline Fuel index & 86.16 & 19.32 & 0.22 & 1.72 & 7.79 \\
\hline Ex-fuel index & 94.76 & 6.08 & 0.06 & 0.25 & 2.39 \\
\hline Overall price index (OPI) & 95.18 & 5.95 & 0.06 & -0.30 & 2.45 \\
\hline
\end{tabular}

Source: Prepared by the author on the basis of data from the Central Bank of Bolivia. 
FIGURE 3

Bolivia: Volatility of export commodity prices

(Coefficient of cumulative annual variability)
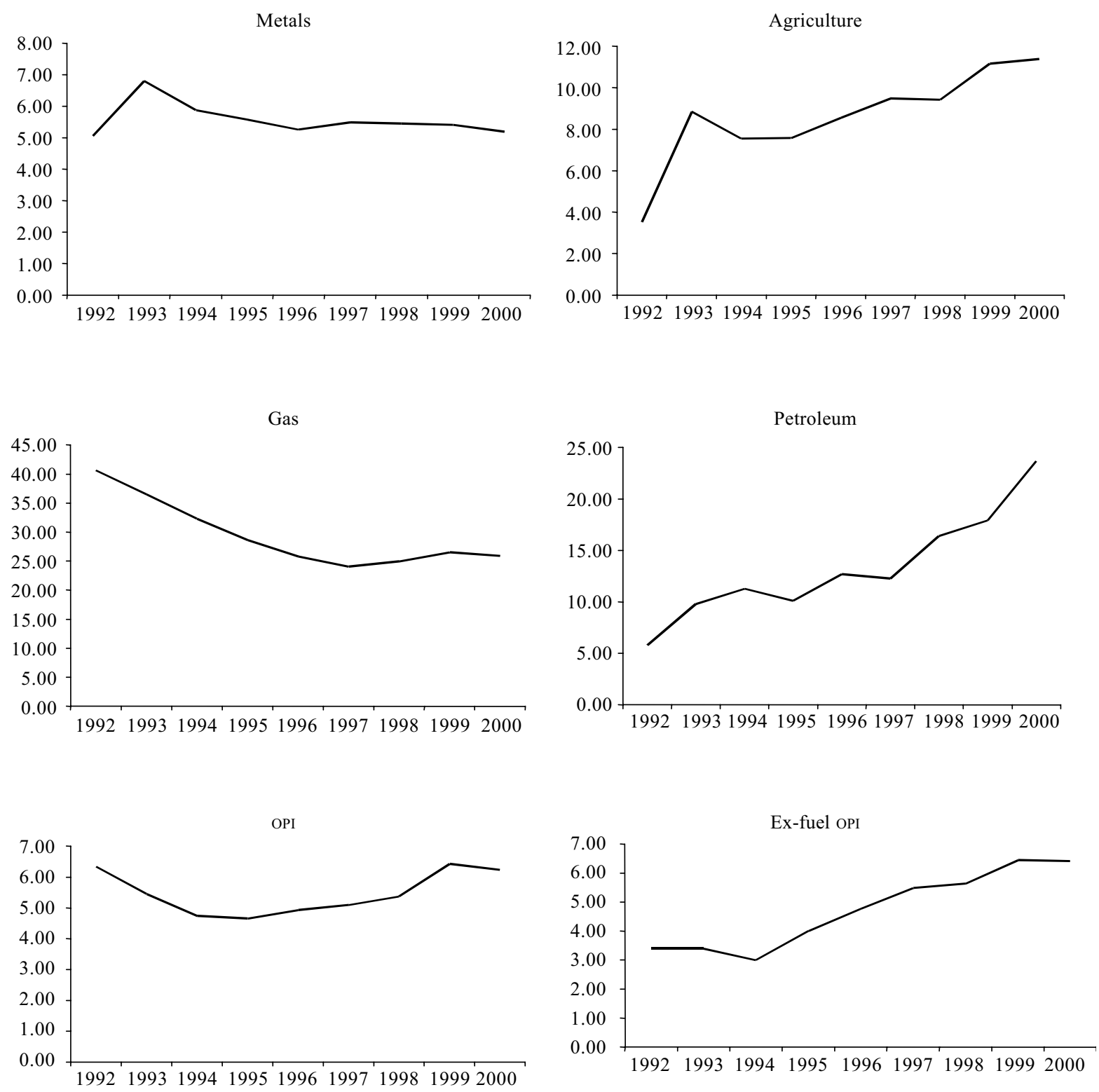

increasing. At the sectoral level, the volatility of metal prices was fairly constant over the period, while both agricultural and petroleum commodities became more volatile. The international crisis led to greater volatility in all export sectors; this increase was neither simultaneous nor constant, however. For metals, volatility rose in 1997 but then fell, while for agricultural commodities it rose in the early stages of the crisis in 1997, fell in 1998 and then rose again in

1999. Fuel prices were more volatile in 1998 and 2000. The end result was that the ex-fuel index was more volatile in 1997 and 1999, while the overall index was more volatile in 1999 only.

For illustrative purposes, and to complete the description of the frequency distributions, the other statistics relating to the directions of price series data dispersion around their centre will be given. The characteristics concerned are asymmetry and kurtosis 
or pointedness. The frequency distribution of the overall price index has a negative asymmetry (the mode, the value that occurs most frequently, is higher than the mean), i.e., the distribution has a longer tail to the left, or towards small values of the variable, while the exfuel index has a positive asymmetry (the mode is lower than the mean), i.e., the distribution has a longer tail to the right. Most mining sector commodity prices have a negative asymmetry. The frequency distribution of commodity prices as measured using the overall index and the ex-fuel index presents a flatter (leptokurtic) distribution. However, the main mining commodities, those of the soya complex and fuels present a more pointed or platykurtic frequency distribution than normal, indicating that the values cluster more closely around the average.

To sum up, Bolivia's overall price index does not display high volatility when compared with prices in developing countries generally (see, for example, Reinhart and Wickham, 1994). Metal prices are the least volatile and fuel prices the most volatile. While the volatility of agricultural prices is intermediate, soya meal, soya oil, coffee, sugar and cotton are the most volatile commodities in the Bolivian export basket. The international crisis increased price volatility in 1997 and again in 1999.

\section{Commodity export portfolio risk}

To ascertain whether the country's implicit strategy of diversifying commodity exports reduced export portfolio risk, the first step was to calculate the matrices of variances and covariances among the product and sectoral price indices, after which portfolio risk was calculated using the following formula:

$R=w_{1}{ }^{2} s_{1}{ }^{2}+w_{1} w_{2} s_{12}+\ldots+w_{1} w_{n} s_{1 n}+\ldots+w_{n-1} w_{n} s_{n-1 n}+w_{n}{ }^{2} s_{n}{ }^{2}$

where:

$R=$ portfolio risk

$W_{\mathrm{i}}=\mathrm{V}_{\mathrm{i}} / \mathrm{V}_{\mathrm{t}}=$ value of sector or product $i /$ total value of the portfolio

$S_{i}=$ variance of the price index for sector or product $i$

$S_{i j}=$ covariance of the price indices for sectors and products $i$ and $j$

$n=$ number of sectors or products

Analysis of the matrix of variances and covariances shows that risk declines when covariances are negative, as fluctuations in product prices offset one another, i.e., there are negative coefficients of correlation that reduce portfolio risk.
In the case of Bolivia, the total risk for the whole commodity export basket is positive (40.67), and the same is true at the sectoral level (38.8), in relation to an index of 100 (table 8). This indicator suggests that while the structure of commodity export sectors is diversified, this has not resulted in risk diversification.

To determine the degree to which inclusion of a new sector increases or reduces risk, the results of including new products from the soya complex in an existing basket like metals are shown (table 9). It can be seen that the original risk of 30.11 in the mining sector rises to a total risk of 35.49 when this complex is included.

When we come to specific product prices, however, the covariance analysis reveals compensation effects, as the following results show:

- Altogether, there are 31 pairs of commodities with negative covariances out of a total of 78 pairs, i.e., the intrasectoral and intersectoral compensation rate is $40 \%$.

- Intrasectoral compensation is greatest in mining with three product pairs out of six, these being zinc and gold (-0.66), zinc and silver (-0.58) and gold and silver $(-0.30)$. This means that, contrary to expectations, price fluctuations within the precious metals sector offset one another. The compensation rate in the agricultural sector is $30 \%$ (seven out of 22 product pairs), it being noteworthy that there is no compensation within the soya complex. There is compensation between wood and this complex, between coffee and sugar $(-0.11)$ and between wood and coffee $(-0.75)$.

- There is a significant level of intersectoral compensation, 21 out of a total of 31 product pairs having negative covariances. Setting the mining

TABLE 8

Bolivia: Sectoral matrix of variances and covariances

(Commodity price indices: $1996=100)$

\begin{tabular}{lccr}
\hline & Metals & $\begin{array}{c}\text { Agricultural } \\
\text { sector }\end{array}$ & Fuels \\
\hline Metals & 5.91 & & \\
Agricultural sector & 3.24 & 16.26 & \\
Fuels & 2.12 & 3.50 & 7.78 \\
\hline Weighted summation of variances & & 29.95 \\
Weighted summation of covariances & & 8.87 \\
Overall risk & & 38.82 \\
\hline
\end{tabular}

Source: Prepared by the author on the basis of data from the Central Bank of Bolivia. 
TABLE 9

Bolivia: Metals and soya complex portfolio

A. Starting scenario: metals portfolio

\begin{tabular}{lrrrr}
\hline & Zinc & Gold & Tin & Silver \\
\hline Zinc & 20.55 & & & \\
Gold & -3.12 & 7.32 & & \\
Tin & 1.97 & 0.18 & 2.33 & \\
Silver & -2.73 & -1.42 & 0.22 & 4.80 \\
\hline Weighted summation of variances & & 35.00 \\
Weighted summation of covariances & & -4.89 \\
Overall risk & & & 30.11 \\
\hline
\end{tabular}

B. Final scenario: metals portfolio plus soya complex

\begin{tabular}{lrrrrrrr}
\hline & Zinc & Gold & Tin & Silver & Soya & Meal & Oil \\
\hline Zinc & 9.35 & & & & & & \\
Gold & -1.42 & 3.33 & & & & & \\
Tin & 0.90 & 0.08 & 1.06 & & & & \\
Silver & -1.24 & -0.64 & 0.10 & 2.18 & & & \\
Soya & 0.77 & 0.83 & -0.24 & -0.51 & 1.85 & & \\
Meal & 1.95 & 2.49 & 0.12 & -1.02 & 2.89 & 7.94 & \\
Oil & 0.21 & 1.06 & 0.09 & -1.14 & 0.68 & 0.63 & 3.18 \\
\hline Weighted summation of variances & & & & 28.90 \\
Weighted summation of covariances & & & 6.59 \\
Overall risk
\end{tabular}

Source: Prepared by the author on the basis of data from the Central Bank of Bolivia.

sector against the agricultural sector, the main features are the negative covariances between silver and agricultural commodities (except wood) and the compensation between the zinc price and the prices of woods, cotton and sugar. Taking the agricultural and mining sectors, it is found in particular that soya offsets silver and tin, sugar offsets mining products (except gold) and wood offsets zinc and gold.

- Comparing the fuels and mining sectors shows silver offsetting gas and petroleum and gold offsetting petroleum. Taking the fuel and agricultural sectors, petroleum is found to present negative covariances with everything except cotton. The price of gas, which will be the main export product, moves in a different direction to those of silver, woods and coffee; note that there is no compensation between the gas price and the soya complex. However, the gas price was influenced by the lower rates set in the contract with Argentina, so in future it could behave much like the petroleum price, which moves against the prices of most other products.

In summary, there is no reduction of risk at the sectoral level because prices move in the same direction. At the product level, however, price movements both within sectors and among them produce large compensation effects. These effects are most common among export products in the mining sector, particularly precious metals. As regards intersectoral movements, silver strongly offsets fuels and most agricultural products, and soya strongly offsets silver, tin and petroleum. The gas price is only offset by a very few products.

\section{VI}

\section{Conclusions and recommendations}

\section{Conclusions}

The recent empirical and theoretical literature has not attached the same importance to commodity price shocks as to financial crises, although it is once again giving some weight to the subject of persistence in price shocks. Empirical evidence has been found to show that they are persistent, and that the downward phase of price movements lasts longer than the upward phase. In other words, there is information to support the idea that commodity prices are in long-term decline. However, other evidence runs counter to the perception that commodity prices are falling across the board.

The poor performance of Bolivia's exports stands in contrast to the dynamism of world exports, most of which are manufactures. The reason for this is that Bolivia is highly dependent on commodity exports (84\% of total exports in 1999), whose prices declined significantly in the $1990 \mathrm{~s}$, resulting in a sharp deterioration in the terms of trade. Nonetheless, the composition of Bolivian exports is not dominated by just a few products, as is the case in most developing 
countries, and nor are they dependent on any particular sector. This should have reduced the country's external vulnerability. The results of this study show, however, that risk has not fallen, cycles have not been evened out, and the volatility of export prices has not decreased.

Bolivian export commodity prices display cyclical behaviour against a declining trend, with upward movements having about the same duration as downward movements. In the declining phase following the Asian crisis, price falls slightly exceeded the price rises seen in the upward phase. If the trend is smoothed, the downward phase lasted much longer than the recovery phase. The short-term price shock in Bolivia really made itself felt in May 1998 when prices fell below trend, although the decline had begun in June 1997.

Permanent shocks help explain the variance of monthly prices. There is a permanent component in Bolivia's price shocks, albeit a smaller one than in developing countries generally. At the sectoral level, this component is largest (but not very persistent) for metals. Consequently, the recent price fall has not tended to correct itself quickly. The relative size of permanent shocks is greatest for metal prices, $69 \%$ of whose monthly variance is due to the permanent component, while in the agricultural and fuel sectors the figure is about $25 \%$, and in the overall price indices, including and excluding fuels, it is about $30 \%$. For metal prices, the permanent component displays a low degree of persistence.

In the case of Bolivia, by contrast with other developing countries, there was found to be a high degree of concordance at the sectoral level, indicating that commodity export diversification has not served to soften the effects of the price cycle, and thus has not been countercyclical in its effects. At the product level, however, it transpires that a third of all exports are of commodities with countercyclical prices, examples being silver and tin (13.1\% of all exports in 1996) against soya beans and soya meal (14.3\%), and silver against gas (8\%).

The overall index is not highly volatile when compared with the level of volatility identified for developing countries in general by the other studies referred to. Metal prices are the least volatile and fuel prices the most volatile. Agricultural prices in general are of only intermediate volatility, but specific products such as soya meal, soya oil, coffee, sugar and cotton are among the most volatile in the Bolivian export basket. The international crisis increased price volatility in 1997 and again in 1999.
When the portfolio risk method is applied to Bolivia's export basket (it was not used in the similar studies on developing countries mentioned in the theoretical discussion), it transpires that expanding the export portfolio by introducing a new commodity export sector, the soya complex, has not reduced overall risk. If the individual products in the export basket are taken, however, a significant percentage of compensation is found $(40 \%)$ within and between sectors. Within sectors, the largest effects of this kind are in the mining sector and among precious metals. In the agricultural sector, compensation runs at $30 \%$ and is not found within the soya complex.

There is a significant level of compensation between the mining and agricultural sectors. Particularly striking are the negative covariances between silver and agricultural commodities, except wood, and the compensation between the soya price and the prices of silver and tin. Taking the fuel and mining sectors, silver offsets gas and petroleum and gold offsets petroleum. Between the fuel and agricultural sectors, petroleum displays negative covariances with all agricultural products except cotton, but gas displays few compensation effects.

The prospects for the export sector centre on silver mining and gas exports; the two products are found to behave in a complementary way, which lessens the impact of adverse shocks. Firstly, the volatility of the silver price is low while that of the gas price is very high. Secondly, silver and gas prices move in different directions, so that the two products can help to reduce risk and, being countercyclical, to soften the phases of the cycle.

\section{Policy recommendations}

It is not advisable for the country to persist with a strategy based principally on exporting a diversifying range of commodities. In the $1990 \mathrm{~s}$, this did nothing to reduce risk, smooth cycles, reduce export price volatility or increase real export revenues.

The empirical evidence has shown that Bolivia needs to supplement its commodity export diversification strategy with an explicit manufacturing export development strategy which, unlike the neutral policy applied hitherto, should include selective production and export promotion policies with a view to reducing external vulnerability in the face of adverse commodity price shocks. This means that structural measures are needed to reduce the country's high degree of external vulnerability. 
Exchange-rate policy should include the behaviour of commodity prices, and most importantly the terms of trade, among the range of indicators it tracks. It should be used to help offset adverse shocks, as these have negative implications for export levels and economic activity.

Permanent shocks, when they occur, lessen the effects of the commodity price stabilization policies recommended by IMF. But the existence of a large transitory component makes it advisable for Bolivia to apply transitory or short-term measures, such as the provision of funds under IMF financial assistance programmes when export revenues fall, and the application of stabilization funds to some strategic commodity such as soya, following the example of Chile with copper.

\section{Bibliography}

Bielschowsky, R. (1998): "Evolución de las ideas de la CEPAL", Revista de la CEPAL, special issue, LC/G.2037-P, Santiago, Chile, Economic Commission for Latin America and the Caribbean (ECLAC), October.

Borensztein, E., M. Khan and others (1994): The Behavior of NonOil Commodity Prices, Occasional paper, No. 112, Washington, D.C., International Monetary Fund (IMF), August.

Cashin, P., H. Liang and C. McDermott (1999): How Persistent Are Shocks to World Commodity Prices?, IMF working paper, No. 80, Washington, D.C., International Monetary Fund (IMF), June.

Cashin, P., J. McDermott and A. Scott (1999a): Booms and Slumps in World Commodity Prices, IMF working paper, No. 155, Washington, D.C., International Monetary Fund (IMF), November.

(1999b): The Myth of Comoving Commodity Prices, IMF working paper, No. 169, Washington, D.C., International Monetary Fund (IMF), December.

Cashin, P. and C. Patillo (2000): Terms of Trade Shocks in Africa: Are They Short-Lived or Long-Lived?, IMF working paper, No. 72, Washington, D.C., International Monetary Fund (IMF), April.

Dehn, J. (2000a): The Effects on Growth of Commodity Price Uncertainty and Shocks, Policy research working paper, No. 2455, Washington, D.C., World Bank.

(2000b): Commodity Price Uncertainty in Developing Countries, Policy research working paper, No. 2426, Washington, D.C., World Bank.

ECLAC (1969): El pensamiento de la CEPAL, Santiago, Chile, Editorial Universitaria.

Hodrick, R. and E. Prescott (1997): Post-war U.S. business cycles: An empirical investigation, Journal of Money, Credit and Banking, vol. 29, No. 1, Columbus, Ohio, Ohio State University.

Krueger, A. (1984): Trade policies in developing countries, in W. Jones and P.B. Kenen (eds.), Handbook of International
Economics, vol. I, Amsterdam, The Netherlands, NorthHolland.

Larson, D., P. Varangis and N. Yabuki (1998): Commodity Risk Management and Development, Washington, D.C., World Bank.

Lewis, W.A. (1960): “Desarrollo económico con oferta ilimitada de mano de obra", El trimestre económico, vol. XXVII (4), No. 108, Mexico City, Fondo de Cultura Económica (FCE).

Moya, R. (1991): Estadística descriptiva, Lima, Editorial San Marcos.

Núñez del Prado, A. (1969): "Estadística básica para planificación", Cuadernos del ILPES, series I, No. 5, Santiago, Chile, Latin American and Caribbean Institute for Economic and Social Planning (ILPES).

Prebisch, R. (1952): Theoretical and Practical Problems of Economic Growth, Mexico City, ECLAC.

(1962): The economic development of Latin America and its principal problems, Economic Bulletin for Latin America, vol. 7, No. 1, Santiago, Chile, ECLAC.

Reinhart, C. and P. Wickham (1994): Commodity prices: Cyclical weakness or secular decline?, Staff Papers, vol. 41, No. 2, Washington, D.C., International Monetary Fund (IMF), June.

Ros, J. (1998): "Relación del intercambio y desarrollo desigual", Revista de la CEPAL, special issue, LC/G.2037-P, Santiago, Chile, Economic Commission for Latin America and the Caribbean (ECLAC), October.

Singer, H.W. (1950): The distribution of gains between investing and borrowing countries, The American Economic Review, vol. 40, No. 2, Nashville, Tennessee, American Economic Association.

Sprout, R. (1992): The ideas of Prebisch, CEPAL Review, No. 46, LC/G.1717-P, Santiago, Chile, ECLAC.

Varangis, P., T. Akiyama and D. Mitchell (1995): Managing Commodity Booms and Busts, Washington, D.C., World Bank.

WTo (World Trade Organization) (2000): Annual report 2000, Geneva. 